\title{
Genetic population structure of the pelagic mollusk Limacina helicina in the Kara Sea
}

\author{
Galina Anatolievna Abyzova ${ }^{\text {Corresp.. }}{ }^{1}$, Mikhail Aleksandrovich Nikitin ${ }^{2}$, Olga Vladimirovna Popova ${ }^{2}$, Anna \\ Fedorovna Pasternak ${ }^{1}$ \\ ${ }^{1}$ Shirshov Institute of Oceanology, Russian Academy of Sciences, Moscow, Russia \\ 2 Belozersky Institute for Physico-Chemical Biology, Lomonosov Moscow State University, Moscow, Russia \\ Corresponding Author: Galina Anatolievna Abyzova \\ Email address: abyzova.ga@ocean.ru
}

Background. Pelagic pteropods Limacina helicina are widespread and can play an important role in the food webs and in biosedimentation in Arctic and Subarctic ecosystems. Previous publications have shown differences in the genetic structure of populations of $L$. helicina from populations found in the Pacific Ocean and Svalbard area. Currently, there are no data on the genetic structure of $L$. helicina populations in the seas of the Siberian Arctic. We assessed the genetic structure of $L$. helicina from the Kara Sea populations and compared them with samples from around Svalbard and the North Pacific.

Methods. We examined genetic differences in L. helicina from three different locations in the Kara Sea via analysis of a fragment of the mitochondrial gene COI. We also compared a subset of samples with $L$. helicina from previous studies to find connections between populations from the Atlantic and Pacific Oceans.

Results. 65 individual L. helinica from the Kara Sea were sequenced to produce 19 different haplotypes. This is comparable with numbers of haplotypes found in Svalbard and Pacific samples (24 and 25, respectively). Haplotypes from different locations sampled around the Arctic and Subarctic were combined into two different groups: $\mathrm{H} 1$ and $\mathrm{H} 2$. The $\mathrm{H} 2$ includes sequences from the Kara Sea and Svalbard, was present only in the Atlantic sector of the Arctic. The other genetic group, $\mathrm{H} 1$, is widespread and found throughout all $L$. helicina populations. $\phi S T$ analyses also indicated significant genetic difference between the Atlantic and Pacific regions, but no differences between Svalbard and the Kara Sea.

Discussion. The obtained results support our hypothesis about genetic similarity of L. helicina populations from the Kara Sea and Svalbard: the majority of haplotypes belongs to the haplotype group $\mathrm{H} 2$, with the $\mathrm{H} 1$ group representing a minority of the haplotypes present. In contrast, in the Canadian Arctic and the Pacific Ocean only haplogroup $\mathrm{H} 1$ is found. The negative values of Fu's Fs indicate directed selection or expansion of the population. The reason for this pattern could bean isolation of the Limacina helicina population during the Pleistocene glaciation and a subsequent rapid expansion of this species after the last glacial maximum. 


\section{Genetic population structure of the pelagic mollusk}

\section{Limacina helicina in the Kara Sea}

3 Galina Anatolievna Abyzova ${ }^{1}$, Mikhail Aleksandrovich Nikitin ${ }^{2}$, Olga Vladimirovna

4 Popova $^{2}$, Anna Fedorovna Pasternak ${ }^{1}$

$5{ }^{1}$ Shirshov Institute of Oceanology, Russian Academy of Sciences, Moscow, Russia

62 Belozersky Institute for Physico-Chemical Biology, Lomonosov Moscow State

7 University, Moscow, Russia

8 Corresponding Author:

9 Galina Abyzova ${ }^{1}$

1036, Nahimovskiy prospekt, Moscow, 117997, Russia

11 Email address: abyzova.ga@ocean.ru

\section{Abstract}

13 Background.Pelagic pteropods Limacina helicina are widespread and can play an 14 important role in the food webs and in biosedimentation in Arctic and Subarctic 15 ecosystems. Previous publications have shown differences in the genetic structure of 16 populations of $L$. helicina from populations found in the Pacific Ocean and Svalbard area. Currently, there are no data on the genetic structure of $L$. helicina populations in the seas of the Siberian Arctic. We assessed the genetic structure of L. helicina from the Kara Sea populations and compared them with samples from around Svalbard and 20 the North Pacific.

21 Methods. We examined genetic differences in L. helinica from three different locations 22 in the Kara Sea via analysis of a fragment of the mitochondrial gene COI. We also 23 compared a subset of samples with $L$. helicina from previous studies to find connections between populations from the Atlantic and Pacific Oceans.

25 Results. 65 individual L. helicina from the Kara Sea were sequenced to produce 19 26 different haplotypes. This is comparable with numbers of haplotypes found in Svalbard 
27 and Pacific samples (24 and 25, respectively). Haplotypes from different locations 28 sampled around the Arctic and Subarctic were combined into two different groups: $\mathrm{H} 1$ 29 and $\mathrm{H} 2$. The $\mathrm{H} 2$ includes sequences from the Kara Sea and Svalbard, was present only 30 in the Atlantic sector of the Arctic. The other genetic group, $\mathrm{H} 1$, is widespread and found 31 throughout all $L$. helicina populations. $\phi S T$ analyses also indicated significant genetic 32 difference between the Atlantic and Pacific regions, but no differences between 33 Svalbard and the Kara Sea.

34 Discussion.The obtained results support our hypothesis about genetic similarity of $L$. 35 helicina populations from the Kara Sea and Svalbard: the majority of haplotypes 36 belongs to the haplotype group $\mathrm{H} 2$, with the $\mathrm{H} 1$ group representing a minority of the 37 haplotypes present. In contrast, in the Canadian Arctic and the Pacific Ocean only 38 haplogroup $\mathrm{H} 1$ is found. The negative values of Fu's Fs indicate directed selection or expansion of the population. The reason for this pattern could bean isolation of the Limacina helicina population during the Pleistocene glaciation and a subsequent rapid expansion of this species after the last glacial maximum.

\section{Introduction}

43

44 45 46 47 48 49

Pelagic pteropods Limacina helicina (Phipps, 1774) are widespread in marine Arctic and Subarctic ecosystems, where their local abundance and biomass are comparable to or greater than that of copepods (Bernard \& Froneman, 2005; Hunt et al., 2008). Pteropods are able to form locally dense aggregations in the water column (Percy \& Fife, 1985). Limacina helicina is the main food of many zooplankton organisms and predators of higher trophic levels, such as fish, whales, and birds (Hunt et al., 2008), and play a key role in the food web and in biosedimentation (Gilmer \& Harbison, 1986; Noji et al., 1997; Bernard \& Froneman, 2009; Manno et al., 2009).

The body of Limacina helicina is covered by a fragile calcium carbonate shell that protects them from predation. The aragonite composition of the shell makes these animals extremely sensitive to ocean acidification, which is expected to increase due to anthropogenic $\mathrm{CO}_{2}$ emissions into the atmosphere (Teniswood et al., 2016). Consequently, this species represents a good model organism for ecological, 
56 physiological and biogeographical studies on how climate change is affecting the Arctic 57 Ocean (Comeau et al., 2009; Lischka et al., 2011).

58 Despite the important role of pteropods in Arctic ecosystems, little is known about 59 the genetic structure of Limacina helicina populations. A high diversity of haplotypes 60 was found in local populations from the fjords of Svalbard (Sromek et al., 2015), 61 including haplotypes typical of these pteropods in the Pacific Ocean (Shimizu et al., 62 2017). However, studies on the genetic structure of Limacina helicina have not been 63 carried out in the Siberian Arctic seas.

64 In the Kara Sea, pteropods are a common component of the pelagic community and 65 their spatial distribution is patchy (Arashkevich et al., 2010; Flint et al., 2015) similar to 66 the other areas (Percy \& Fife, 1985). Within patches, their abundance reached one 67 million ind. $\mathrm{m}^{-2}$, and they are the dominant consumers of suspended matter and 68 phytoplankton (Drits et al., 2015).

The Kara Sea is a typical shelf for the Siberian Arctic Sea: the warm, salty water 70 from the Barents Sea enters from the south into the Kara Sea, and the cold Arctic water 71 penetrates from the north (Zatsepin et al., 2015). We expect that the genetic structure of 72 the populations of Limacina helicina in the Kara Sea is similar to that in the Svalbard 73 region, which is also influenced by the Barents Sea and Arctic basin waters (Stiansen \& 74 Filin, 2007). In the Kara Sea, however, the effect of waters of different origin, combined 75 with the impact of a strong river run-off, creates a mosaic of biotopes, where the genetic structure of populations can be different. We tested these hypotheses by examining intraspecific diversity of Limacina helicina in the Kara Sea using a fragment of the mitochondrial gene COI.

\section{Materials \& Methods}

80

Limacina helicina were selected from zooplankton samples collected during the cruise \#63 of the RV Akademik Mstislav Keldysh in the Kara Sea that took place September-October 2015. Samples were collected at three different locations: station

835265 in the south of the Kara Sea and two stations in the Voronin and St. Anna troughs, 84 5239 and 5212, respectively (Fig. 1, Table 1). In the top $20 \mathrm{~m}$ of the water column at the 85 station AMK 5265 temperature was $6{ }^{\circ} \mathrm{C}$ and salinity was 31.4. At station AMK 5239 
86 temperature was $1.2{ }^{\circ} \mathrm{C}$ and salinity was 30 (this station is affected by freshwater runoff 87 and melting ice), while at station AMK 5212 in the St. Anna trough was $4.3^{\circ} \mathrm{C}$ and 88 salinity was 34.3 .

Pteropods were preserved in $96 \%$ ethanol immediately after collection. DNA was isolated from a piece of the pteropodia of large individuals $(1-7 \mathrm{~mm})$ or from the whole animal in case of small individuals $(0.1-0.7 \mathrm{~mm})$ using the ExtraGene ${ }^{\mathrm{TM}}$ DNA Prep 100 kit (Isogen, Moscow, Russia) per the manufacturer's protocol.

Fragments of mitochondrial cytochrome oxidase subunit gene (COI) were amplified using Encyclo Plus PCR kit (Eurogen, Moscow, Russia) using two standard primers: TAAACTTCAGGGTGACCAAAAAATCA-3') (Folmer et al., 1994). PCR was conducted using the following common PCR cycle settings: $5 \mathrm{~min}$ at $95^{\circ} \mathrm{C}, 40$ cycles of $95^{\circ} \mathrm{C}$ for 30 $\mathrm{s}$, followed by annealing at $48^{\circ} \mathrm{C}$ for $45 \mathrm{~s}, 72^{\circ} \mathrm{C}$ for $1 \mathrm{~min}$, and then a final elongation at $72^{\circ} \mathrm{C}$ for $5 \mathrm{~min}$. PCR products were analyzed with a $1 \%$ agarose gel electrophoresis, purified and sequenced using Applied Biosystems ${ }^{\circledR} 3500$ Genetic Analyzer. Subsequently sequences were aligned and analyzed using MEGA 6.0 (Tamura et al., 2013). The $503 \mathrm{bp}$ fragments of $\mathrm{COI}$ gene were used for comparison with all other $L$.

103 helicina samples from the Arctic and Pacific available from the GenBank database 104 (Table 1). Low quality contigs (contigs containing more than $3 \mathrm{Ns}$ ) were excluded from analysis. The software Popart 1.7 (Leigh \& Bryant, 2015) was then used for comparative analysis and identification of differences between populations as well as for construction of a TCS haplotype network (Clement et al., 2002). Furthermore, the program DnaSP (Rozas et al., 2017) was used for an estimation of genetic diversity in populations. Finally, the Arlequin 3.5 (Excoifer \& Lischer, 2010) software was used for pairwise $\phi S T$ calculations between regions analysis and verification of neutrality.

111 Significance of $\phi S T$ was tested with 1000 permutations

\section{Results}

We analyzed 73 specimens of $L$. helicina from the Kara Sea. COI sequences were 114 obtained from 65 of these samples, and 8 sequences were discarded due to poor 115 quality contigs, leaving 57 individual sequences for further analysis. The highest $\phi S T$ 
116 value found between the southern and northern parts was 0.023 (n. s.) (Table 2). Due to 117 the lack of significant differences in genetic structure between the three different Kara 118 Sea collection locations, the data from these stations were combined for comparison 119 with Svalbard and Pacific populations. In total, 179 L. helicina sequences from the Arctic 120 and Pacific were downloaded from GenBank (Table 1). These sequences were 121 regarded as three large geographical subgroups: the Kara Sea, Svalbard (data from 122 Sromek et al., 2015), and the Pacific (Jennings et al., 2010; Chichvarkin, 2016; Shimizu 123 et al., 2017). We also added the data from the Canadian Arctic (Hunt et al., 2010; 124 Jennings et al., 2010; Layton, Martel \& Hebert, 2014) for the haplotype network 125 construction. A total of 65 haplotypes were found from all sequences, which were 126 combined in two large haplogroups, which differ from each other by 2 nucleotide 127 substitutions (Fig. 2B). Each haplogroup represents a typical star-like haplonet with 128 numerous branches. These patterns are in agreement with analysis of Shimizu et al 129 (2017) and so we adopted their names of haplogroups as $\mathrm{H} 1$ and $\mathrm{H} 2$. Haplogroup $\mathrm{H} 2$ 130 includes the majority of sequences from the Kara Sea and Svalbard, while the H1 is 131 widespread at all research locations and found throughout all $L$. helicina populations 132 (Table 1).

133 The samples from Kara Sea were represented by 19 haplotypes with two being 134 widespread (Fig. 2A). The remaining haplotypes are structured by their variations, 135 differing by 1-3 nucleotide substitutions. The majority of the Kara Sea individuals are 136 represented by the $\mathrm{H} 2$ haplogroup $(79 \%)$. The greatest variability of haplotypes was 137 found at the St. Anna Trough in the north of the sea. The H2 haplogroup was also the 138 predominant haplogroup found in samples from Svalbard fjords $(84 \%)$, while only $\mathrm{H} 1$ 139 haplogroups were found in the Pacific region (Fig. 2B). The highest haplotype diversity 140 (Table 3) was reported around Svalbard $(\mathrm{H}=0.771)$. The diversityof haplotypes in the 141 Kara Sea is similar $(H=0.672)$, despite a smaller number of analyzed individuals. The 142 diversityof haplotypes in Pacific is significantly lower $(\mathrm{H}=0.449)$ as well as nucleotide 143 diversity (Table 3 ). The Tajima's D and Fu's Fs neutral evolution model tests showed 144 significant negative values (Table 3).

145 The haplotype network (Fig. 2B) shows similarity between the Kara Sea and 146 Svalbard populations. The ratio between the $\mathrm{H} 2$ and the $\mathrm{H} 1$ haplogroups in this region 
147 is also similar - the majority of individuals belongs to the $\mathrm{H} 2$ haplogroup. All individuals

148 from Canadian Arctic and Pacific share the H1 haplogroup.

149 Pairwise comparison of $\phi S T$ showed no significant differences between the Kara

150 Sea and the Svalbard populations $(\phi S T=-0.00109, n$. S.), however the samples from

151 the Kara Sea and Svalbard differed significantly from the Pacific (Table 2).

152 Discussion

153 The obtained results support our hypothesis that $L$. helicina populations from the Kara 154 Sea would be genetically similar to those near Svalbard.

155 The haplotype network is very similar for populations from the Kara Sea and those from 156 the North of the Atlantic near Svalbard (Fig. 2B), and the ratio of haplotype group H2 157 haplotype group $\mathrm{H} 1$ is also similar. The majority of haplotypes belongs to haplotype 158 group H2, a minor part to the group H1. In contrast, in the Canadian Arctic and the 159 Pacific only haplogroup $\mathrm{H} 1$ is found. The $\mathrm{H} 1$ group of haplotypes is widespread and 160 occurs at all stations and populations (Table 1, Fig. 3), and populations from the Pacific 161 Ocean and the Canadian Arctic were almost identical and were represented by the 162 same sequence. This is explained by the main currents through the Bering Strait and 163 indicates the possible direction of distribution of plankton communities from the Pacific 164 Ocean (Nelson et al., 2009; Questel et al., 2016). Typical star-like haplonet and the 165 conducted Tajima's D and Fu's Fs tests can point to the rapid population expansion. 166 The negative values of Fu's Fs indicate the presence of a large number of low 167 frequency haplotypes, usually described for loci under directed selection or expansion 168 of the population after a severe decline (however, see Niwa et al., 2016, for an 169 alternative explanation of negative $D$ and $F$ in abundant marine organisms). The reason 170 for this pattern could be the rapid expansion of this species after the last glacial 171 maximum. Similar dispersal was observed for other Arctic species that have survived in 172 the refugia, then quickly spread to their current habitats after the deglaciation (Hewitt, 173 2000; Weydmann et al., 2017).

174 According to the previous studies (Sromek, Lasota, \& Wolowicz, 2015; Shimizu et al., 175 2017), Limacina helicina were formerly widely distributed in the Arctic and the Pacific, 176 but the populations were isolated in the Northern Atlantic during the 
177 glaciation.Haplotype group $\mathrm{H} 1$ may have persisted in a Pacific refuge, and $\mathrm{H} 2$ - in an 178 Atlantic refuge. Subsequently, during the retreat of the glacier about $131 \mathrm{ky} \mathrm{BP}$, there 179 was an increase in genetic diversity and distribution around Svalbard (Sromek et al, 180 2015). A similar spread of Pacific fauna was shown for other groups of organisms in the 181 Atlantic region (Laakkonen et al., 2013). The recent distribution of $L$. helicina haplotypes 182 could be explained in a similar way. When the ice sheets disappeared between the 183 Pacific and Atlantic, the Pacific population could have resettled in the Arctic. This 184 hypothesis is supported by the existence of a separated haplotype group $\mathrm{H} 1$ along with 185 haplotype group H2 (Fig. 3). The currents flowing between the Pacific and the Arctic 186 through the Bering Strait have a predominantly northward direction (see references in 187 Questel et al., 2016). This lends support to a hypothesis that Limacina helicina may only 188 effectively migrate from the Pacific into the Arctic and not the other way around, which is 189 consistent with our observation that the $\mathrm{H} 1$ haplogroup has reached the Arctic, while the $190 \mathrm{H} 2$ haplogroup appears to be absent from the Pacific (Fig. 3)

191 The absence of significant differences between the Kara Sea and Svalbard and the 192 similarity of proportions of different haplotypes in these regions is consistent with an 193 ongoing or recent exchange between these two populations, which coincides with the 194 oceanography in this area (Stiansen \& Filin, 2007).

195 Frequency of occurrence of different haplotypes varies between locations of the 196 Kara Sea (near the Kara Strait, the St. Anna and Voronin Troughs), but these 197 differences are not significant. In the south (station AMK 5265 near the Kara Strait), the 198 percentage $\mathrm{H} 1$ haplotype $(14 \%)$ is lower than in the north at St. Anna or Voronin 199 Troughs (st. AMK 5239, 5212) (26\%). This is in accordance with the penetration of 200 water of different origins into the sea: in the south-west at station AMK 5265, the warm 201 and salty water of the Barents Sea origin penetrates through the Kara Strait, while the 202 northern part of the Kara Sea is strongly influenced by the Arctic saline and cold water 203 (Zatsepin et al. 2015). Since these populations were not significantly different 204 genetically, the different environments are not isolating either population.

205 Conclusions 
206 This study represents the first research on the genetic structure of Limacina helicina in 207 the Kara Sea and makes an important contribution to zooplankton phylogeography by 208 providing data on this large Arctic sea, which is not easily accessible. The comparison 209 of our own data from the Kara Sea with the published data obtained in the Svalbard 210 area, northwest Pacific, and Canadian Arctic, allowed us to conclude that the 211 distribution of haplotypes in the Kara Sea is similar to that in Svalbard. Although no 212 significant differences between habitats within the Kara Sea were found, the proportion 213 of haplotypes $\mathrm{H} 2$ was higher near the Kara Strait than in the northern troughs. The 214 analysis of the available data provides insight into the population structure of this 215 pteropod species, indicating possible direction of post-glacial distribution of Limacina 216 helicina in the Arctic. However, many questions regarding the genetics of this mollusk in 217 the Arctic still remain unresolved, and in future studies we hope to better understand 218 how far the western population of Limacina helicina penetrates and how the haplotypes 219 are distributed over other Arctic seas.

\section{Acknowledgements}

221 For the help in the collection of Limacina helicina and discussion of this project we 222 would like to thank A.V. Drits, as well as V.V. Aleshin and C. Gross for extremely helpful 223 comments on this manuscript. We are particularly grateful for the laboratory assistance 224 from the 2017 Invertebrate Zoology bachelor students (Lomonosov Moscow State 225 University). In addition, we gratefully acknowledge the native English speaker Elizabeth 226 Schmidt for constructive comments of the manuscript. We thank Pieternella 227 Luttikhuizen, Katharina Jörger and an anonymous reviewer for important and valuable 228 comments that significantly improved the paper.

\section{References}

230

231

232

233

1. Arashkevich EG, Flint MV, Nikishina AB, Pasternak AF, Timonin AG, Vasilieva JV, Mosharov SA, Soloviev KA. 2010. The role of zooplankton in the transformation of the organic matter in the Ob estuary, on the shelf, and in the deep regions of the Kara Sea. Oceanology. 50(5):780-792. 
234 2. Bernard KS, Froneman PW. 2005. Trophodynamics of selected

235

236

237

238

239

240

241

242

243

244

245

246

247

248

249

250

251

252

253

254

255

256

257

258

259

260

261 mesozooplankton in the west-Indian sector of the Polar Frontal Zone, Southern Ocean. Polar Biology28(8):594-606.

3. Bernard KS, Froneman PW. 2009. The sub-Antarctic euthecosome pteropod, Limacina retroversa: Distribution patterns and trophic role. Deep Sea Research Part I: Oceanographic Research Papers 56(4):582-598.

4. Chichvarkhin A. 2016. Shallow water sea slugs (Gastropoda: Heterobranchia) from the northwestern coast of the Sea of Japan, north of Peter the Great Bay, Russia. PeerJ. 4, e2774-e2774.

5. Clement M, Snell Q, Walker P, Posada D, Crandall K. 2002. TCS: Estimating gene genealogies. Parallel and Distributed Processing Symposium, International Proceedings. 2: 184.

6. Comeau S, Gorsky G, Jeffree R, Teyssié JL, Gattuso JP. 2009. Impact of ocean acidification on a key arctic- pelagic mollusc (Limacina helicina). Biogeosciences. 6:1877-1882.

7. Drits AV, Arashkevich EG, Nikishina AB, Sergeeva VM, Solovyev KA, Flint MV. 2015. Mesozooplankton grazing impact on phytoplankton in the northern regions of the Kara Sea in autumn. Oceanology. 55(4):595-605.

8. Excoffier L, Lischer HEL. 2010. Arlequin suite ver 3.5: A new series of programs to perform population genetics analyses under Linux and Windows. Molecular Ecology Resources. 10:564-567.

9. Flint MV, Poyarkov SG, Timonin AG, Soloviev KA. 2015. The structure of the mesoplankton community in the area of the continental slope of the St. Anna trough (Kara Sea). Oceanology. 55(4):583-594.

10. Folmer O, Black M, Hoeh W, Lutz R, Vrijenhoek R. 1994. DNA primers for amplification of mitochondrial cytochrome $\mathrm{c}$ oxidase subunit I from diverse metazoan invertebrates. Molecular Marine Biology and Biotechnology. 3(5):294299. 
262 11. Gilmer RW, Harbison GR. 1986. Morphology and field behavior of pteropod

263

264

265

266

267

268

269

270

271

272

273

274

275

276

277

278

279

280

281

282

283

284

285

286

287

288

289 molluscs: feeding methods in the families Cavoliniidae, Limacinidae and Peraclididae (Gastropoda: Thecosomata). Marine Biology.91(1):47-57.

12. Hewitt G. 2000. The genetic legacy of the Quaternary ice ages. Nature, 405(6789):907-913.

13. Hunt B, Strugnell J, Bednarsek N, Linse K, Nelson RJ, Pakhomov E, Würzberg L. 2010. Poles apart: the "bipolar" pteropod species Limacina helicina is genetically distinct between the Arctic and Antarctic oceans. PLoS One. 5(3):e9835.

14. Hunt BPV, Pakhomov EA, Hosie GW, Siegel V, Ward P, Bernard K. 2008. Pteropods in Southern Ocean ecosystems. Prog Oceanogr. 78:193-221.

15. Jennings RM, Bucklin A, Ossenbrügger H, Hopcroft RR. 2010. Species diversity of planktonic gastropods (Pteropoda and Heteropoda) from six ocean regions based on DNA barcode analysis. Deep Sea Research Part II: Topical Studies in Oceanography. 57(24): 2199-2210.

16. Laakkonen HM, Lajus DL, Strelkov P, Väinölä R. 2013. Phylogeography of amphi-boreal fish: tracing the history of the Pacific herring Clupea pallasii in North-East European seas. BMC Evolutionary biology.13(1):67.

17. Layton KK, Martel AL, Hebert PD. 2014. Patterns of DNA barcode variation in Canadian marine molluscs. PLoS One. 9(4):e95003.

18. Leigh JW, Bryant D. 2015. popart: full-feature software for haplotype network construction. Methods in Ecology and Evolution. 6(9):1110-1116.

19. Lischka S, Büdenbender J, Boxhammer T, Riebesell U. 2011. Impact of ocean acidification and elevated temperatures on early juveniles of the polar shelled pteropod Limacina helicina: mortality, shell degradation, and shell growth. Biogeosciences.8(4):919.

20. Manno C, Tirelli V, Accornero A, Fonda Umani S. 2009. Importance of the contribution of Limacina helicina faecal pellets to the carbon pump in Terra Nova Bay (Antarctica). Journal of Plankton Research.32(2):145-152. 
21. Nelson RJ, Carmack EC, McLaughlin FA, Cooper GA. 2009. Penetration of Pacific zooplankton into the western Arctic Ocean tracked with molecular population genetics. Marine Ecology Progress Series.381:129-138.

293

22. Niwa, H. S., Nashida, K., \& Yanagimoto, T. 2016. Reproductive skew in Japanese sardine inferred from DNA sequences. ICES Journal of Marine Science, 73(9), 2181-2189.

296

23. Noji TT, Bathmann UV, Bodungen BV, Voss M, Antia A, Krumbholz M, Klein B, Peeken I, Noji CIM, Rey F. 1997. Clearance of picoplankton-sized partides and formation of rapidly sinking aggregates by the pteropod, Limacina retroversa. Journal of Plankton Research.19(7):863-875.

300

301

24. Percy JA, Fife FJ. 1985. Energy distribution in an Arctic coastal macrozooplankton community. Arctic. 38:39-42.

302

25. Questel JM, Blanco-Bercial L, Hopcroft RR, Bucklin A. 2016. Phylogeography 303

304

305 and connectivity of the Pseudocalanus (Copepoda: Calanoida) species complex in the eastern North Pacific and the Pacific Arctic Region. Journal of plankton research.38(3):610-623.

306

307

308

309

26. Rozas J, Ferrer-Mata A, Sánchez-DelBarrio JC, Guirao-Rico S, Librado P, Ramos-Onsins SE, Sánchez-Gracia A. 2017. DnaSP 6: DNA Sequence Polymorphism Analysis of Large Datasets. Mol. Biol. Evol. 34:3299-3302. DOI: 10.1093/molbev/msx248.

311

27. Schlitzer, R. 2018. Ocean Data View, odv. awi. de.

312

28. Shimizu K, Kimoto K, Noshita K, Wakita M, Fujiki T, Sasaki T. 2017. Phylogeography of the pelagic snail Limacina helicina(Gastropoda: Thecosomata) in the subarctic western North Pacific. Journal of Molluscan Studies. 1-8.

29. Sromek L, Lasota R, Wolowicz M. 2015. Impact of glaciations on genetic diversity of pelagic mollusks: Antarctic Limacina antarctica and Arctic Limacina helicina. Marine Ecology Progress Series. 525:143-152. 
318 30.Stiansen JE, Filin A. 2007. Joint PINRO/IMR report on the state of the Barents Sea ecosystem in 2006 with expected situation and considerations for management.

321 31. Tamura K, Stecher G, Peterson D, Filipski A, Kumar S. 2013. MEGA6: molecular evolutionary genetics analysis version 6.0. Molecular biology and evolution. 30(12):2725-2729.

324 32. Teniswood CM, Roberts D, Howard WR, Bray SG, Bradby JE. 2016. Microstructural shell strength of the Subantarctic pteropod Limacina helicina antarctica. Polar Biology. 39(9):1643-1652.

33. Weydmann A, Przyłucka A, Lubośny M, Walczyńska KS, Serrão EA, Pearson GA, Burzyński A. 2017. Postglacial expansion of the Arctic keystone copepod Calanus glacialis. Marine Biodiversity. 1-9.

34.Zatsepin AG, Poyarkov SG, Kremenetskiy VV, Nedospasov AA, Shchuka SA, Baranov VI, Kondrashov AA, Korzh AO. 2015. Hydrophysical features of deep water troughs in the western Kara Sea. Oceanology. 55(4):472-484. 


\section{Figure 1}

Location of the stations in the Kara Sea where L. helicina were collected.

Schlitzer, R., Ocean Data View, https://odv.awi.de, 2018.

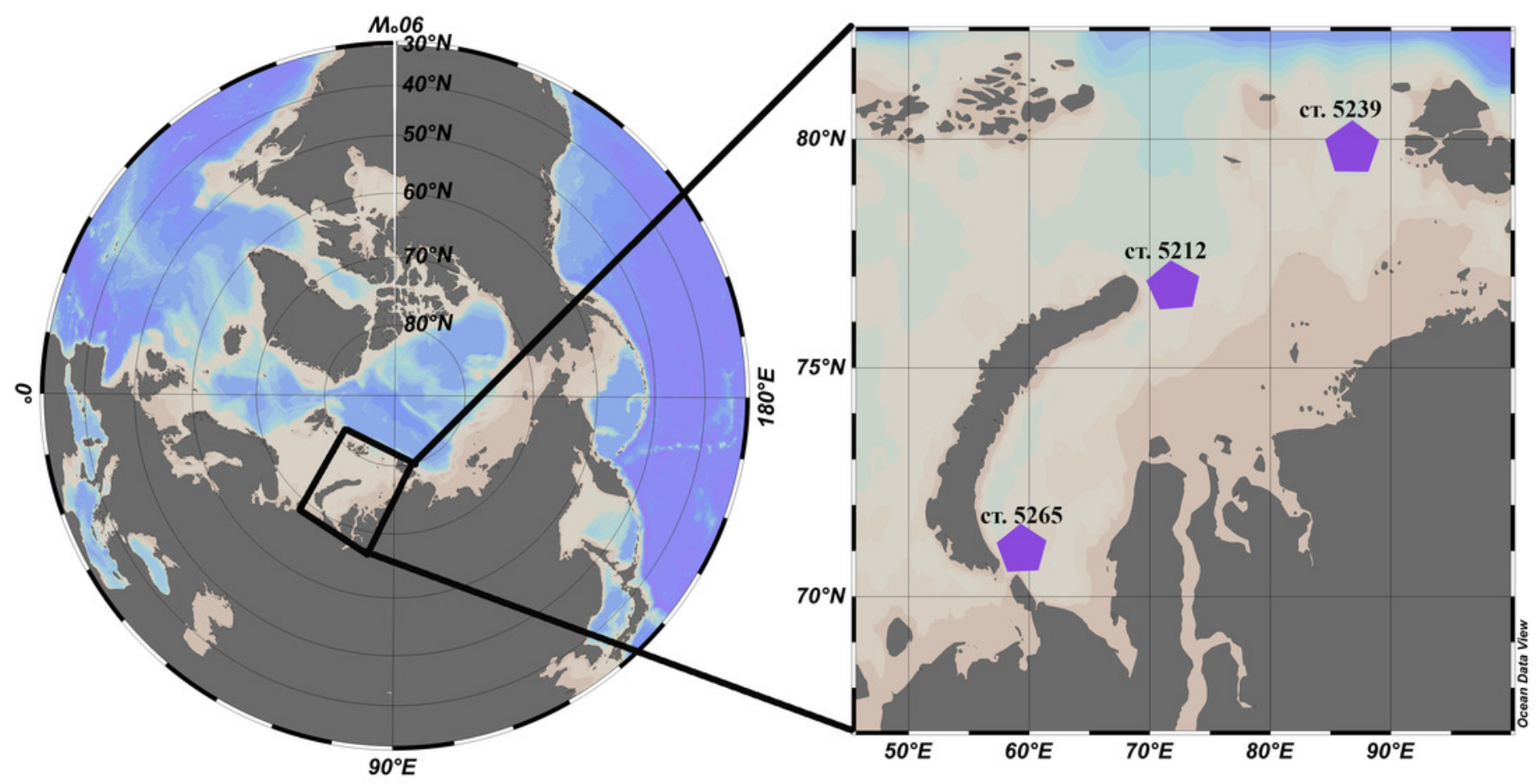




\section{Table $\mathbf{1}$ (on next page)}

Geographical location of Limacina helicina samples and compositions of haplotypes.

$\mathrm{N}$ - number of analyzed individuals, $\mathrm{H} 1$ and $\mathrm{H} 2$ - haplogroups. 


\begin{tabular}{|c|c|c|c|c|c|c|}
\hline \multirow{2}{*}{ Location } & \multicolumn{2}{|c|}{ Coordinates/ References } & \multirow[t]{2}{*}{$\mathrm{N}$} & \multirow[t]{2}{*}{ Haplogroup } & \multirow{2}{*}{$\begin{array}{l}\mathrm{N} \text { from } \\
\text { haplogroup }\end{array}$} & \multirow{2}{*}{$\begin{array}{l}\text { GenBank } \\
\text { accession } \\
\text { number }\end{array}$} \\
\hline & $\mathrm{N}^{\circ}$ & $\mathrm{E}^{\circ}$ & & & & \\
\hline \multirow{2}{*}{$\begin{array}{l}\text { Kara Sea, South } \\
\text { St. } 5265\end{array}$} & \multirow[t]{2}{*}{$70^{\circ} 53$} & \multirow[t]{2}{*}{$58^{\circ} 18$} & \multirow[t]{2}{*}{22} & H1 & 3 & \multirow{2}{*}{$\begin{array}{l}\text { MH379290 - } \\
\text { MH379311 }\end{array}$} \\
\hline & & & & $\mathrm{H} 2$ & 19 & \\
\hline \multirow{2}{*}{$\begin{array}{l}\text { Kara Sea, } \\
\text { Voronina } \\
\text { Trough, St. } 5239\end{array}$} & \multirow[t]{2}{*}{$78^{\circ} 36$} & \multirow[t]{2}{*}{$88^{\circ} 04$} & \multirow[t]{2}{*}{12} & $\mathrm{H} 1$ & 2 & \multirow{2}{*}{$\begin{array}{l}\text { MH379312- } \\
\text { MH379330 }\end{array}$} \\
\hline & & & & $\mathrm{H} 2$ & 10 & \\
\hline \multirow{2}{*}{$\begin{array}{l}\text { Kara Sea, } \\
\text { St. Anna Trough, } \\
\text { St. } 5212\end{array}$} & \multirow[t]{2}{*}{$76^{\circ} 43$} & \multirow[t]{2}{*}{$70^{\circ} 59$} & \multirow[t]{2}{*}{23} & $\mathrm{H} 1$ & 7 & \multirow{2}{*}{$\begin{array}{l}\text { MH379266 - } \\
\text { MH379289 }\end{array}$} \\
\hline & & & & $\mathrm{H} 2$ & 16 & \\
\hline \multirow[t]{2}{*}{ Svalbard } & \multirow{2}{*}{\multicolumn{2}{|c|}{ Sromek et al., 2015}} & \multirow[t]{2}{*}{68} & $\mathrm{H} 1$ & 11 & \multirow{2}{*}{$\begin{array}{l}\text { AB859527 - } \\
\text { AB859593 }\end{array}$} \\
\hline & & & & $\mathrm{H} 2$ & 57 & \\
\hline \multirow[t]{2}{*}{ Pacific Ocean } & \multirow{2}{*}{\multicolumn{2}{|c|}{$\begin{array}{l}\text { Jennings et al., } 2010 \\
\text { Chichvarkin, } 2016 \\
\text { Shimizu et al., } 2017\end{array}$}} & \multirow[t]{2}{*}{105} & H1 & 105 & \multirow[b]{2}{*}{$\begin{array}{l}\text { FJ876923, } \\
\text { KX871888, } \\
\text { KX871889, } \\
\text { LC185015- } \\
\text { LC185073, } \\
\text { LC229727- } \\
\text { LC229769 }\end{array}$} \\
\hline & & & & $\mathrm{H} 2$ & 0 & \\
\hline \multirow[t]{2}{*}{ Canadian Arctic } & \multirow{2}{*}{\multicolumn{2}{|c|}{$\begin{array}{l}\text { Hunt et al., } 2010 \\
\text { Layton et al., } 2014 \\
\text { Jennings et al., } 2010\end{array}$}} & \multirow[t]{2}{*}{6} & $\mathrm{H} 1$ & 6 & \multirow{2}{*}{$\begin{array}{l}\text { GQ861826- } \\
\text { GQ861828, } \\
\text { HM862494, } \\
\text { HM862496, } \\
\text { FJ876924 }\end{array}$} \\
\hline & & & & $\mathrm{H} 2$ & 0 & \\
\hline
\end{tabular}




\section{Table 2 (on next page)}

Pairwise Phi-st values and associated $p$-values among Limacina helicina populations from the three sampling sites in Kara Sea and three different geographical areas.

Significant differences $(p<0.001)$ are in bold. 
1

\begin{tabular}{|l|c|c|}
\hline Compared areas & Фst & p-value \\
\hline St Anna - Voronin & 0.01574 & 0.21622 \\
\hline St Anna - South & 0.02292 & 0.15315 \\
\hline Voronin - South & -0.00263 & 0.42342 \\
\hline \multicolumn{3}{|c|}{ Between different seas } \\
\hline Kara Sea - Svalbard & -0.00109 & 0.47748 \\
\hline Kara Sea - Pacific & $\mathbf{0 . 6 3 4 2 2}$ & $\mathbf{0 . 0 0 0 0 0}$ \\
\hline Svalbard - Pacific & $\mathbf{0 . 6 0 0 1 3}$ & $\mathbf{0 . 0 0 0 0 0}$ \\
\hline
\end{tabular}

2 
Figure 2

TCS network of Limacina helicina haplotypes.

(A) haplotypes from Kara Sea (this study). St. Anna trough is marked in light green, Voronin through - in black, and southern part of Kara Sea - in dark green. (B) haplotypes across Northern hemisphere based on the current research and the GenBank data. Svalbard population is marked in dark blue, the Kara Sea in green, Pacific in orange, and the Canadian Arctic in blue. $\mathrm{H} 1$ - haplogroup 1, H2 - haplogroup 2.

Notes: each haplotype is colored according to the location where it was collected. Haplotype circle sizes indicate frequency (according to the Table 1).
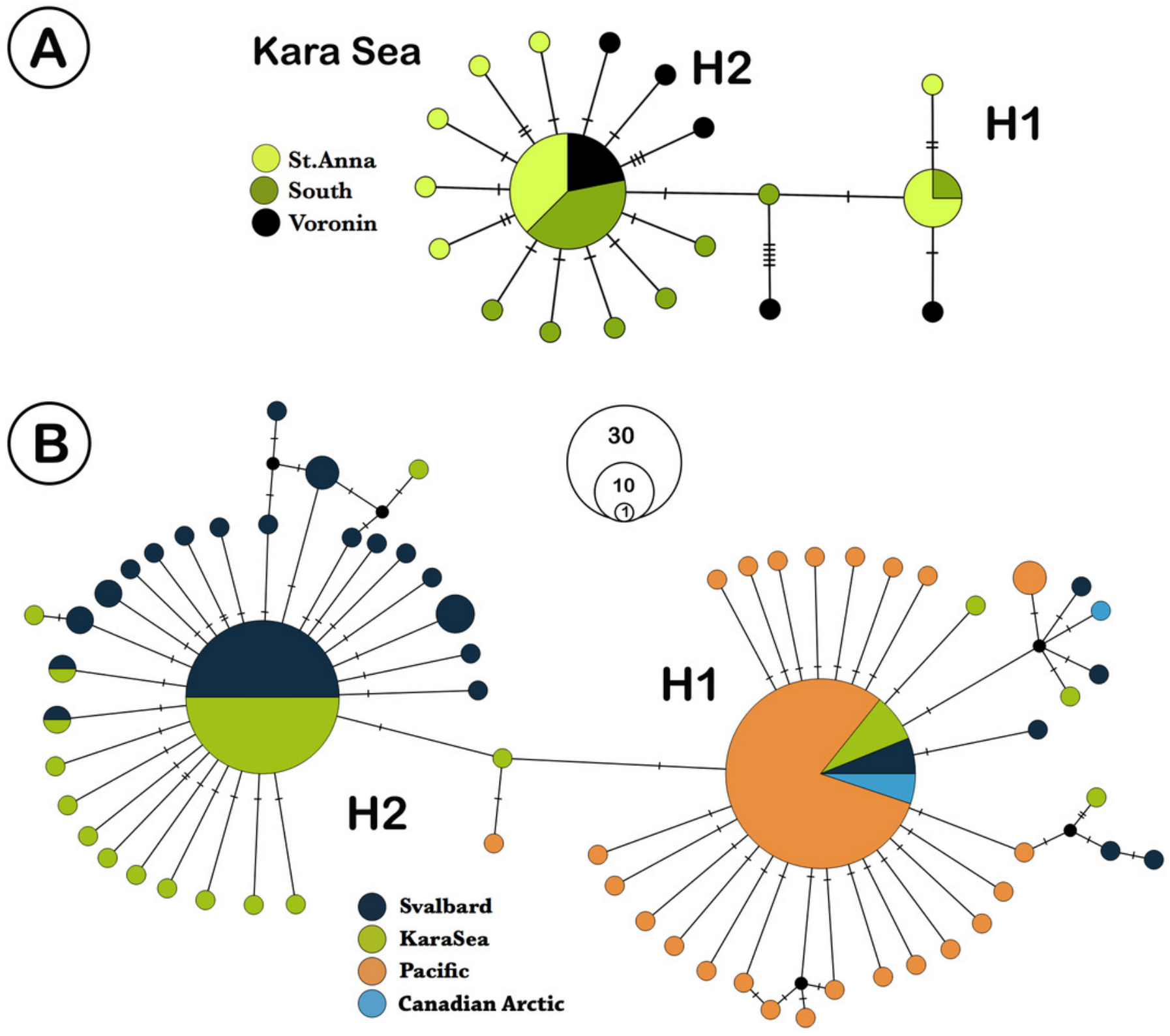


\section{Table 3(on next page)}

Estimates of genetic diversity in populations ofLimacina helicina from regions of Arctic and Pacific Ocean. Nucleotide and haplotype diversity, neutrality test.

Notes:

N: number of individuals; Ns: number of sites; k: number of haplotypes; S: polymorphic sites; H: haplotype diversity; $\boldsymbol{\pi}:$ nucleotide diversity; (ח): average number of nucleotide differences; D: Tajima's D; Fs: Fu's Fs neutrality test. 
1

\begin{tabular}{|l|l|l|l|l|l|l|l|l|l|}
\hline & $\mathbf{N}$ & $\mathbf{N} \mathbf{k}$ & $\mathbf{k}$ & $\mathbf{S}$ & $\mathbf{H}$ & $\boldsymbol{\pi}$ & $\mathbf{\Pi}$ & $\mathbf{D}$ & Fs \\
\hline Kara Sea & 57 & 500 & 19 & 26 & 0,672 & 0,00301754 & 1,509 & $\begin{array}{l}-2,35896 \\
(\mathrm{p}<0.001)\end{array}$ & $\begin{array}{l}-17,725 \\
(\mathrm{p}<0.0001)\end{array}$ \\
\hline Svalbard & 68 & 503 & 24 & 25 & 0,771 & 0,00338705 & 1,704 & $\begin{array}{l}-2,10848 \\
(\mathrm{p}<0.01)\end{array}$ & $\begin{array}{l}-24,253 \\
(\mathrm{p}<0.0001)\end{array}$ \\
\hline Pacific & 105 & 503 & 26 & 26 & 0,449 & 0,00124309 & 0,625 & $\begin{array}{l}-2,60329 \\
(\mathrm{p}<0.001)\end{array}$ & $\begin{array}{l}-42,81 \\
(\mathrm{p}<0.0001)\end{array}$ \\
\hline
\end{tabular}

2 
Figure 3

Haplotype distribution among the Arctic populations of Limacina helicina.

Orange - haplogroup H1, Blue - haplogroup H2. Schlitzer, R., Ocean Data View, https://odv.awi.de, 2018.

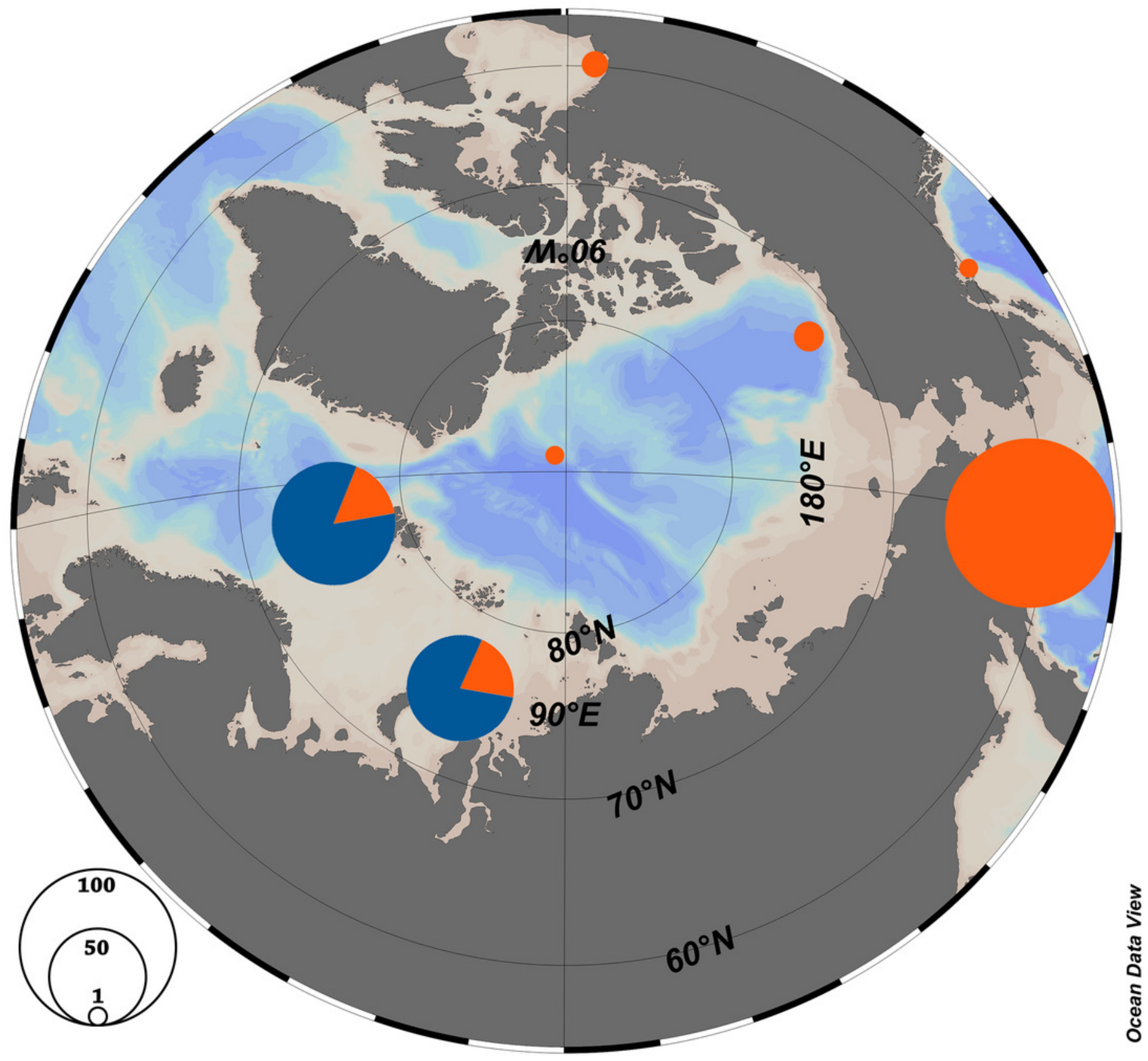

